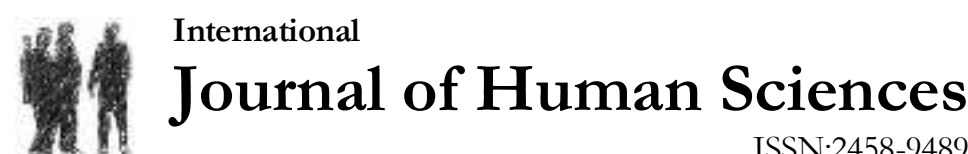

Volume 14 Issue 4 Year: 2017

\section{Nigerian foreign policy approach towards ECOWAS}

\author{
Dennis Osasuyi Omo-Ogbebor ${ }^{1}$
}

\begin{abstract}
The foreign policy of a state actor towards inter-governmental organizations has become a predominant feature in the contemporary world order, and Nigeria is an active member of the international community. Its foreign policy towards ECOWAS since its formation in 1975 is examined based on its contributions to the regional organization. The objectives of this article are; to explain the historical background of Nigerian foreign policy after gaining independence from Great Britain in 1960; to analyze Nigerian foreign policy approach towards ECOWAS at the early stage of the organization and, finally, to evaluate Nigerian foreign policy in the direction of ECOWAS after its return to democratic rule in 1999. The application of the content analytical method is to realize the objectives set out in the article to allow the author gives a basic conclusion. Therefore, the evolving geopolitics of the world has shown that foreign policy is an effective mechanism in projecting a country's image and policy direction abroad in modern international relations system.
\end{abstract}

Keywords: Nigeria; Foreign policy; ECOWAS; West Africa; Inter-governmental organization.

\section{Introduction}

The framework of Nigerian foreign policy formed the basic perception how it sees the world from ideological, political, economic, and religious standpoints. These factors decide its foreign policy response to regional and continental affairs. Nigeria is a key player in West Africa sub-region, Africa, and global stage, especially in the activities of the regional inter-governmental organization ECOWAS. Nigerian foreign policy approach towards ECOWAS regional agenda is based on Afrocentric foreign policy doctrine which is the premise of its foreign policy direction after attaining independence to support the cause of African countries struggling for independence in the 1960s. Nigerian Afrocentric foreign policy doctrine was effective at the regional level which was directed at its West African neighbors because Nigeria sees the West African region as its natural territory.

The Afrocentric foreign policy doctrine is the cardinal point of Nigerian foreign policy direction over the years. According to Akintola, Nigeria has maintained a relatively consistent foreign policy because the country had experienced varied forms of government within this period. Right from independence Africa was the centerpiece of Nigerian foreign policy with emphasis on the emancipation, development, and unity of Africans both within and outside the continent (Akintola, 2007, p.439).

\footnotetext{
${ }^{1} \mathrm{PhD}$ Candidate, People's Friendship University of Russia Moscow. Department of Theory and History of International Relations.samsuyi2002@yahoo.co.uk
} 
The enormous contribution of Nigeria to regional development coincided to the emergence of ECOWAS in 1975 as an inter-governmental regional organization. The effort was to prove its ability to play a larger role in the international community beyond the West African region. The end of the bipolar world in the 1990s allowed regional state actors to play more active role in regional affairs, which also gave rise to Nigerian influence in West African regional affairs. In the assessment of Otunbajo, Nigeria could play a leadership role in Africa because of the dwindled strategic significance of major external powers (Otunbajo, 1989). However, Nigerian foreign policy towards ECOWAS is two-level approach through bilateral and multilateral diplomatic dealing with state actors in regional affairs. Thus, foreign policy is a plan of action adopted by one nation regarding its diplomatic dealings with other countries. Foreign policy is established as a systemic way to deal with issues that may arise with other countries (Business Dictionary, 2017).

The contemporary globalization agenda of the world system, no nation can afford to be in isolation in this period of uneven distribution of scarce natural resources and human labor in this era of interdependence. Emphasis is now attached to the foreign policy direction of a nation. Accordingly, foreign policy has a range of actions, as well as a set of principles influencing these actions, taken regarding external situations and factors, the summation of thoughts, actions, and principles on external affairs taken by decision-makers with the intention of achieving long-range goals and short-term objective (Frankel, 1978). The aim of this article is to analytically review Nigeria's foreign policy towards ECOWAS as an inter-governmental organization in the West African region within the framework of 1975-2017.

\section{Background of Nigerian Foreign Policy Formation}

Nigerian foreign policy evolution is tied to its political-ideological foundation as ex-colony of Great Britain. Its early role in the international scene was dictated by its ex-colonial administrator Great Britain even after becoming an independent nation on 1st October 1960. Nigerian first Prime Minister Abubakar Tafa Balewa is the pioneering government official whose efforts at foreign policy-making and implementation laid the groundwork of Nigeria's role and influence in international politics, and unconsciously, casting a part and credible image for the country in the community of nations. Since gaining independence, Nigeria's foreign policy has progressed despite setback along its political and developmental stages which include decolonization, regime change from civilian to the military; unitary, federal, parliamentary, and presidential systems of government, the endless transition to democratic rule.

Howbeit, the presence of Nigeria as a newly independent nation became known at the international political front because of its membership of various international organizations, according to Adebajo, et al, (2008) Nigeria is a member of the United Nations, Commonwealth of Nations, Non-Alignment Movement, pioneer member of the Organization of African Unity $(\mathrm{OAU})$ and equally played an instrumental role in its eventual transformation into the African Union (AU) in 2002 (Adebajo, et al, 2008). Meanwhile, the work of most historical researchers concerning African affairs analyzed it from a historical perspective that, most African countries foreign policies were influenced by ex-colonial administrators in the early stages after they got independence. They argue that the development was due to political link and economic dependence on their ex-colonial administrators by countries in the continent even after the end of colonial rule. This observation made Bondarenko said that most African nations' foreign policies are patterned in line with colonial ideology having been colonized by most of the European countries, thus trying to create an identity for themselves but still have a strong tie with their colonial administrators (Bondarenko, 2008, p.3).

Furthermore, Nigeria colonial history as a former British colony and a member of the Commonwealth invariably constrained Nigeria's predisposition to be pro-Western on most issues despite its nonaligned status to avoid neocolonialism (Folarin, 2010). In fairness, Nigeria's independence in 1960 came at the period of the Cold War. Nigeria, thus, celebrating its new status 
as an independent country with a bright prospect based on its available natural resources and its human potential spread across the board was caught in the contention between the superpower nations dilemma. Nigeria found a relief in the foreign policy of non-alignment which was informed both by its refusal not to take sides in the battle of supremacy and by its membership of the OAU [Shaw, et al, 1983]. This neutral stand by Nigeria became necessary during the cold war because the fight for independence among African countries formed the core of their foreign policy in this era. While the end of the Cold War resulted in a fundamental change in the dynamics of contemporary international relations. Nigeria was notably at the forefront of this fight along with most African countries as anti-colonialism became the most obvious and consistent, and all-embracing common denominator of African foreign policy at the time ([Ibid: Otubanjo, 1989).

Besides, the Nigerian Ministry of Foreign Affairs is a statutory body saddled with the responsibility to reinforce foreign decision making and implementation processes in Nigeria and handle the external promotion of Nigeria's domestic and foreign visions and ideas in conjunction with specialized agencies in helping to formulate these ideas such as the Nigerian Institute of International Affairs (NIIA), Lagos, National Intelligence Agency (NIA) and other statutory bodies. Although, at the early stage of Nigeria's nationhood, the ex-colonial authority was still dictating Nigerian foreign policy abroad. Thus, the enduring nature of the British influence on Nigeria's foreign policy and its ruling elites continued until the late 1960s when the lessons of the civil war of 1967-1970 compelled Nigeria foreign policy elites to reappraise its stand towards external relations (Nuamah, 2003, p.4). The historiography of Nigerian foreign policy since the formation of ECOWAS can be classified into two broad phases which are the formative stage of ECOWAS when Nigeria was mostly under military rule and the second stage when Nigeria returned to democratic rule.

\section{Nigerian Foreign Policy: 1975-1999}

Nigerian foreign policy approach towards ECOWAS after its creation was to consolidate on the Afrocentric foreign policy doctrine it has developed that is well known to the international community before the creation of ECOWAS. This necessitated its determination to lead the newly formed organization right from the beginning to preserve its supposed leadership status in the region. In the opinion of Price, (1975), the foreign policy of a State is liable to reflect the State's personality, but foreign policy cannot be developed in a completely arbitrary manner, since policy is bound to be affected by many considerations concerned with the circumstances and internal problems of the State (Price, 1975, p.181).

Nigerian foreign policy towards ECOWAS during its formative years were also defined by the prevailing circumstances in the region that allows the kind of foreign policy which was premeditated to response to the frequent political instabilities across the region because of incessant military coups, religious intolerance, lack of social-economic development, and supremacy struggle between Anglophone and Francophone countries in the region due to their historical experience. Broadly speaking, during the formative years and the greater part of ECOWAS existence Nigeria was governed by military rulers except for the brief period of Shagari civilian rule from 1979 to 1983. Hence, during that era, Nigeria's status as a non-democratic country under military regime dictated its foreign policy directions towards ECOWAS and the West African regional integration process.

The constant changing of governments through the unconstitutional process was prevalent among ECOWAS members, thereby worsening the political and security situation in the region. This development was the reason political stability and security matters come to dominate the activities of ECOWAS in the 1980s and 1990s instead of economic integration which was the primary reason ECOWAS was formed. Besides, ECOWAS was created during the oil boom period in the world which provided Nigeria with a huge oil revenue to attend to the myriad of problems that confronted the region and sustains the survival of ECOWAS during the turbulent years. 
According to Egbo, (2003) that the revenue from oil provided Nigeria a new impetus to practice her non-aligned stance and position of neutrality in international events. Moreover, this period witnessed the oil revolution which became a very serious economic resource for Nigeria, and with her economy developing, Nigeria began a foreign policy that involved economic expansion into neighboring African states. This would invariably lead to the formation of the Economic Community of West African States (ECOWAS) in May 1975 involving fifteen West African countries (Institute of Army Education, 1977, p.11-13).

It is worth mentioning that Nigerian foreign policy approach towards ECOWAS regional activities under military rule places emphasis on security in the region rather than economic advancement. This form of policy direction was seen by Danjuma, from an acute perception that, Nigeria believed West African instability is a function of poverty and underdevelopment and that in solving what appears purely as political and economic problems, the physical challenges also must be addressed. That, when Nigeria carried out political and military gestures to individual states or groups of states in West Africa, it is also addressing the problems of the sub-region (Danjuma, 2012).

Nevertheless, during the military regime of Buhari in 1983, Nigeria made attempt to create a synergy with its three neighbors to the West, Benin, Ghana, and Togo, whom a multilateral agreement was signed to promote cooperation among the four countries in the areas of economic, security and culture in line with ECOWAS topmost regional agenda of integrating the member states. Even though, Nigerian foreign policy has been characterized by a focus on Africa as a regional power and by attachment to several fundamental principles: African unity and independence; capability to exercise hegemonic influence in the region: peaceful settlement of disputes; non-alignment and non-intentional interference in the internal affairs of other nations; and regional economic cooperation and development (Wachuku, 1961, p.20).

Nigeria's initial step in having well designed foreign policy template can be traced to the Akinyemi doctrine of "Reciprocity in Nigerian Foreign Policy" formulated during Ibrahim Babangida' military regime which is still relevant in subsequence Nigerian foreign policies's formulation. The doctrine states that: Various components of a country's national security interests have a systemic relationship. Therefore, a nation which does not have economic security can at best, only provide temporary relief from internal subversion and external aggression. Similarly, a nation without political stability cannot provide the framework for sustained economic growth and development (Akinyemi, 1987, p.5). The doctrine was the first serious effort made in identifying and defining Nigeria's national interest in political, economic, social and security terms. Indeed, it went further to formulate strategies and instruments for their realization. Nigeria's involvements in ECOWAS and any role it has played in the past few decades had been the result of strongly held opinion by its successive leaderships.

Nigerian foreign policy objectives have allowed it to participe in various ECOWAS regional programs to give credence to the West African regional integration process which has led to the signing of many ECOWAS laws, treaties, protocol agreements and conventions to advance the development and economic growth of the region. Nigerian active role in ECOWAS is a direct response to its foreign policy plans to accommodate the burden of its West African neighbors, to support ECOWAS specific fields of regional initiatives, and to advance the developmental goal of the region which is also in line with United Nations (UN) call for countries involvement in regional cooperation to promote free trade, common market, political stability, security of lives and properties, humanitarian and cultural cooperation.

It is necessary to note that Nigeria's approach towards ECOWAS regional agenda is guided by its foreign policy directions formulated by the Nigerian Ministry of Foreign Affairs. The summary of the main features of Nigeria foreign policy towards the West African region is anchored on the three doctrinal concepts; African center-piece perspective, the concentric circle model which outlines the following: Anti-colonialism, anti-apartheid and anti-racism principles. 
Omo-Ogbebor, D. O. (2017). Nigerian foreign policy approach towards ECOWAS. Journal of Human Sciences, 14(4), 4015-4022. doi:10.14687/jhs.v14i4.4656

Cooperation with immediate neighbors and with other ECOWAS member states and promotion of peace (Ministry of Foreign Affairs, 2011).

\section{Nigerian Foreign Policy Since 1999}

Since returning to democratic rule in 1999, Nigerian foreign policy towards ECOWAS regional agenda is guided by its 1999 constitution which outline the objectives of its foreign policy direction. In section 19 of the 1999 constitution, projects a dynamic foreign policy for Nigeria, through the promotion of economic development, integration and unity, peace and security in West Africa, Africa, and the world. Nigeria returned to democratic government on May 29, 1999, after prolonged years of military rule, the election of Olusegun Obasanjo as President of Nigeria kicks start the fourth republic, drawing the curtain on thirty-five years of military dictatorship and autocratic rule. Also brings hope and relieve to Nigerians and international community especially ECOWAS member states because as an assumed regional leader, it is supposed to lead by example, so Nigeria returned to democratic rule gives credibility and legal ground to ECOWAS' protocol on democracy and good governance.

In his inaugural speech, Obasanjo emphasizes on the need for Nigeria to remain active at the center stage of international affairs, accordingly "We shall pursue a dynamic foreign policy to promote friendly relations with all nations and will continue to play a constructive role in the United Nations and the Organization of African Unity and other international bodies. We shall continue to honor existing agreements between Nigeria and other countries. It is our determination to restore Nigeria fully to her previous prestigious position in the community of nations (Obasanjo's Inaugural Speech, 1999). Nigerian foreign policy approach towards ECOWAS witnessed a proactive response during Obasanjo's tenure as President of Nigeria, he reinforced the country's position as Africa's regional power is sustained and extended. Based on this notion, Africa continued to attract the attention of Nigerian foreign policy, with particular emphasis on the promotion of ECOWAS' regional agenda, development, peace, and security.

Nigerian foreign policy witnessed pro-activeness during Obasanjo' administration, a frantic effort was made to project Nigerian image abroad through its various foreign policy initiatives, particularly in its participation in ECOWAS programs and decision making. According to Ajetunmobi, the first tenure of Obasanjo's presidency was characterized by a deep resolution to translate the country's strategic and comparative advantages into practical rewards and benefits both for the country and for Africa at large (Ajetunmobi, et al, 2011, p.308-315]. Nigerian newfound democratic credential allows its foreign policy to support and promote democratic value in ECOWAS member states and beyond. It sought to ensure that democratic rule became the norm by showing strong resistance for non-democratic regimes among ECOWAS member states within the sub-region.

The Nigerian government, for example, resisted regime changes inspired by military coups particularly in the case of Guinea, Niger, Burkina Faso, and the one of Sao Tome and Principe though not a member of ECOWAS. Another milestone in Nigerian foreign policy during Obasanjo's presidency is in the peaceful resolution of conflicts, the regime of Obasanjo restored confidence and credibility in West Africa by pursuing a Peace Philosophy. He advocated four broad issue areas that Africa must address if it must move towards lasting peace in Africa. These include: redirecting the mind, redefining sovereignty, a redefinition of security, and institutionalization of democracy (Obasanjo, 1999).

Apparently, Nigerian has exhibited its leadership role through various ECOWAS protocols in the peaceful resolution of the political crises in Sierra Leone, Liberia and Togo. Nigeria equally gets involved while playing the lead role in the Mano River dispute between Liberia, Guinea, and Sierra-Leone thus bringing an end to the sequence of hostility prevalent within the region. Subsequently, Nigeria based on its diplomatic skills acquired over the years in its involvement in regional affairs was able to successfully inaugurates the Gulf of Guinea Commission (GGC) in 
Gabon in 1999. The objectives of GGC was aimed at strengthening economic and political ties among its member states as well as establishing a platform for the furtherance of cooperative engagements among sub-regional organizations such as the Economic Community of West African States (ECOWAS) and the Central African Economic Community (CAEC) (Flemes, 2007).

The election of President Umaru Yar'Adua and his subsequent assumption of office on May 29, 2007, was an epic moment because it was the first time a democratically elected president was be transiting power to another democratically elected president in the political history of Nigeria. There was a paradigm shift in Nigerian foreign policy under President Umaru Yar'Adua' administration, which digressed from the traditional Afrocentric doctrine into a practical emphasis on the Nigerian people with Nigerians at the forefront of diplomatic engagements with the rest of the world.

In the view of Pogoson, (2009) this notable foreign policy stance tagged as 'Citizen Diplomacy' requires the government of Nigeria to more consciously resort to the basic needs, human rights, and socio-economic welfare of the citizen in conducting bilateral and multilateral engagements with other nations. This may sound straightforward, but, its normative implications and transformative potentials are enormous (Pogoson, 2009, p.58-73). Although, the basic thrust of the new foreign policy initiative revolves around concerns for the basic needs, human rights and socioeconomic welfare of Nigerian citizens in bilateral and multilateral engagements with other countries.

There is no need to debate the fact that Nigerian natural base in the international community remained in the West African region and in the African continent, and this would continue to remain part of Nigerian foreign policy agenda, even in cases that Nigeria's national interest would take prominence over sub-regional, continental and global issues. The main objective of Yar'Adua administration was to lift Nigeria's economy to become one of the 20 largest economies in the world by the year 2020. This distinct objective showed a clear indication of the priority of domestic interest in shaping the country's foreign policy. The Agenda has been properly conceptualized and comprehensively articulated and the implementation strategies adequately lay out, to ensure the realization of ECOWAS Vision 2020 which Nigerian embraced with all its seriousness (Yar'Adua, 2007). Most Nigerians believe there had been no meaningful balance between Nigeria's external policies and its domestic interests. Therefore, the country had received very little in return for its generosity, its ambitious Afrocentric foreign policy and the extensive sacrifices made in regional and continental diplomacy (Alao, 2011).

The death of President Yar'Adua witnessed a modification in Nigerian foreign policy approach towards ECOWAS, the Jonathan' presidency stressed that only a stable political and economic environment would give Nigeria a robust foreign policy. Economic diplomacy in this sense is conceived as the process through which countries tackle the outside world, to maximize their national gain in all the fields of activity including trade, investment and other forms of economically beneficial exchanges, where they enjoy comparative advantage through bilateral, regional and multilateral dimensions, each of which is important. Nigeria's new foreign policy direction was the focus on investment and economic cooperation, which thus ties foreign policy to the country's domestic agenda, a radical departure from the old one which has Africa as the center point.

Despite modification in its foreign policy objectives, Nigeria continued to demonstrate its support towards ECOWAS zero tolerance for the unconstitutional and undemocratic change of government. Its condemnation of the undemocratic change of government in both Mali and Guinea Bissau is evidence of this fact. Nigeria negotiated a peaceful resolution of the crisis and prevented the coup leaders in those countries from executing their detained erstwhile presidents and prime ministers (Nigerian Ministry of Foreign Affairs, 2013). In furtherance of its leadership position in Africa and more importantly in serving the national strategic interest of the country, 
Nigeria committed about 1200 troops and N7 billion to the intervention in Mali while also pledging the construction of military clinics for the Malian army.

The Nigerian foreign policy under Buhari's presidency towards ECOWAS regional agenda is somewhat a reverse, emphasis is given on internal issues rather than getting too involved with external matter that will drill the country's lean resources. Although, Nigerian foreign policy towards ECOWAS regional security arrangement is not compromised, and its continued support of ECOWAS' stand on unconstitutional change of government is unwavering as demonstrated during Burkina Faso and Gambian political crises.

Nigeria's acceptance of the leadership of the Joint Multinational Military Forces demonstrated its readiness to build a strategic security network to outfit with its West African neighbors to fight against Boko Haram terrorist group and other security threats to Nigeria and to the region. Nigerian government top priority remains its internal challenge to fix its economy. According to President Muhammadu Buhari' inaugural address when he assumed office, pledged to uplift the standard of the citizens of Nigeria, preserving national interest will guide his foreign policy direction in the sub-region of West Africa. However, Nigerian foreign policy is passing through transformation period with no specific agenda except the old age Afrocentric slogan which has dominated its foreign policy formulations since its independence.

By and large, Nigerian foreign policy has passed through various phases since its independence in 1960. Nigerian foreign policy from the very beginning was formulated to serve the interest of the West African region and the African continent. The early setback in Nigerian political development and subsequent internal challenges that followed did not discourage it from extending its assistance and contributions to ECOWAS. Nigeria has proven its worth in Africa especially through the West African regional organization ECOWAS based on its well-articulated and crafted foreign policy, designed to accommodate the needs and challenges arising in the region which every successive Nigerian leader has come to accept and act on.

Nigerian foreign policy approach towards ECOWAS regional activities has remained consistent despite various internal and external challenges confronting its application. Its ages long foreign policy stance of Pro-Africanism which started with its independence, the West African region has remained part of its foreign policy till to date which still continue to guide its role in ECOWAS activities. The various foreign policies of successive governments in Nigeria have in one way or the other contributed to the continuous existence of ECOWAS as a regional intergovernmental organization. Subsequently, Nigerian foreign policy towards ECOWAS regional initiatives has directly or indirectly contributed to the growth of the organization and the development of the region at large especially in spheres of the economic scheme, security formation, and promotion of political stability through democracy and good governance. Therefore, Nigerian engagements in ECOWAS activities are carried out through bilateral and multilateral diplomacy to meet the expectations of the international community as a regional leader.

\section{REFERENCES}

A. Bolaji Akinyemi, (1987), 'Reciprocity in Nigerian Foreign Policy' (The Akinyemi Doctrine) Lagos, Nigerian Institute of International Affairs (NIIA).

Adebajo, A \& Mustapha, R. (Eds.). (2008). Gulliver's troubles: Nigeria's foreign policy after the Cold War. Scottsville, RSA: University of KwaZulu-Natal Press.

Aja Wachukwu, (1961). "Establishing Nigeria' Foreign Policy Identity” Federal Ministry of Foreign Affair, Lagos, Nigeria. 

4015-4022. doi:10.14687/jhs.v14i4.4656

Ajetunmobi, R.O., Osunkoya, O.A. \& T.F. Omotere, T.F. (2011). Impact of president Olusegun Obasanjo's personality on Nigerian foreign policy, 1999-2007. Pakistan Journal of Social Sciences, 8, 308-315.

Akintola, Bukola (December 2007) "Nigeria and the World: A Review of Nigeria's Foreign Policy (1960-2007)". The Nigerian Army Quarterly Journal, 439(4).

Alao, A. (2011). Nigeria and the global powers: Continuity and change in policy and perceptions (Occasional Paper No. 96). South African Foreign Policy and African Drivers Programme. SAIIA.

Ambassador Ashiru, Ministerial briefing, Nigerian Ministry of Foreign Affairs, 2013, Abuja, Nigeria.

Danjuma, T.Y. (2012). Nigeria's Security Role in West Africa. View Article: DOI: http://www.onlinenigeri.com/finance/?blurb=44accessedon06/01/2012

Egbo, Steve (2003) Nigeria and the World: A Treatise on Foreign Policy. Enugu: John Jacobs Classic Publishers.

Flemes, D. (2007). Conceptualising regional power in international relations: Lessons from the South African case (GIGA Working Papers No. 53)

Folarin, S.F. (2010). National role conceptions and Nigeria's African policy, 1985-2007, Covenant University, Otta, Nigeria. View Article: DOI: http://dspace.covenantuniversity.edu.ng/bitstream/handle/123456789/125/Full

Foreign Policy. Business Dictionary, 2017. http://www.businessdictionary.com/definition/foreignpolicy.html

Frankel, J. (1978) International Relations (2Nd Ed.) London: Oxford University Press.

Institute of Army Education (January 1977) "Nigeria's Foreign Policy, 1960-1976”. Nigerian Army Information Briefs, IV (1).

Ministry of Foreign Affairs (MFA) (2011). Submission to the Conference on the Review of Nigerian Foreign Policy, Organized by the Presidential Advisory Council (PAC) in Collaboration with the Ministry of Foreign Affairs (MFA), Conference Hall, MFA, Abuja, August 1-3.

Nuamah, R. (2003), Nigeria's Foreign Policy after the Cold War. Domestic, Regional and External Influences. United Kingdom: International Peace Academy, Oxford, p.4

Obasanjo, O. (1999). Who is Obasanjo. View Article: DOI: http://olusegunobasanjo.org/hiscareer.php

Obasanjo's Inaugural Speech, 29th May 1999, Nigerian Ministry of Foreign Affair, Abuja, Nigeria.

Otunbajo, F. (1989). Introduction: Phases and changes in Nigeria's foreign policy. In A.B. Akinyemi (Ed.), Nigeria since independence: The first 25 years Vol. x 'International Relations'. Ibadan: Heinemann Educational Books Ltd.

Pogoson, A.I. (2009). New dimensions in Nigeria's foreign policy, 1999-2009. Journal of African Culture and Civilization, 2, 58-73.

Price, J.H (1975) Political Institutions in West Africa, Hutchinson of London, p.181

Prof. D.M. Bondarenko, (2008) "The image of modern Russia in Africa: the formation and characteristics (2006-2008)", Institute for African Studies of the Russian Academy of Sciences, Moscow, Russia.

Shaw, T., \& Aluko, O. (1983). Nigerian foreign policy: Alternative perception and projection. London: Macmillan Press Ltd.

Yar'Adua, U.M. (2007). Inauguration Speech of President, 29 May 2007, Nigeria, Federal Ministry of Information \& Communications, Vision 2020. 